\title{
Factors Affecting the Performance of Membrane Osmotic Processes for Bioenergy Development
}

\author{
Wen Yi Chia ${ }^{1}{ }^{\circledR}$, Kuan Shiong Khoo ${ }^{1}$, Shir Reen Chia ${ }^{1} \mathbb{D}$, Kit Wayne Chew ${ }^{2}$, Guo Yong Yew ${ }^{1}$, \\ Yeek-Chia Ho ${ }^{3,4, *(\mathbb{D})}$, Pau Loke Show $1, *(\mathbb{1})$ and Wei-Hsin Chen $5,6,7,8, * \mathbb{C}$
}

1 Department of Chemical and Environmental Engineering, Faculty of Science and Engineering, University of Nottingham Malaysia, Jalan Broga Semenyih 43500, Malaysia; wenyichia@gmail.com (W.Y.C.);

kuanshiong.khoo@hotmail.com (K.S.K.); shireen.chia127@gmail.com (S.R.C.); yewguoyong@gmail.com (G.Y.Y.)

2 School of Mathematical Sciences, Faculty of Science and Engineering, University of Nottingham Malaysia, Jalan Broga Semenyih 43500, Malaysia; KitWayne.Chew@nottingham.edu.my

3 Civil and Environmental Engineering Department, Universiti Teknologi PETRONAS, Seri Iskandar 32610, Malaysia

4 Institute of Self-Sustainable Building, Centre for Urban Resource Sustainability, Universiti Teknologi PETRONAS, Seri Iskandar 32610, Malaysia

5 Department of Aeronautics and Astronautics, National Cheng Kung University, Tainan 701, Taiwan

6 Department of Chemical and Materials Engineering, College of Engineering, Tunghai University, Taichung 407, Taiwan

7 Department of Mechanical Engineering, National Chin-Yi University of Technology, Taichung 411, Taiwan

8 Research Center for Energy Technology and Strategy, National Cheng Kung University, Tainan 701, Taiwan

* Correspondence: yeekchia.ho@utp.edu.my (Y.-C.H.); PauLoke.Show@nottingham.edu.my (P.L.S.); weihsinchen@gmail.com or chenwh@mail.ncku.edu.tw (W.-H.C.)

Received: 4 December 2019; Accepted: 14 January 2020; Published: 19 January 2020

\begin{abstract}
Forward osmosis (FO) and pressure-retarded osmosis (PRO) have gained attention recently as potential processes to solve water and energy scarcity problems with advantages over pressure-driven membrane processes. These processes can be designed to produce bioenergy and clean water at the same time (i.e., wastewater treatment with power generation). Despite having significant technological advancement, these bioenergy processes are yet to be implemented in full scale and commercialized due to its relatively low performance. Hence, massive and extensive research has been carried out to evaluate the variables in FO and PRO processes such as osmotic membrane, feed solutions, draw solutions, and operating conditions in order to maximize the outcomes, which include water flux and power density. However, these research findings have not been summarized and properly reviewed. The key parts of this review are to discuss the factors influencing the performance of $\mathrm{FO}$ and $\mathrm{PRO}$ with respective resulting effects and to determine the research gaps in their optimization with the aim of further improving these bioenergy processes and commercializing them in various industrial applications.
\end{abstract}

Keywords: concentration polarization; draw solution; feed solution; forward osmosis; pressure-retarded osmosis; operating conditions; membrane fouling; osmotic membrane

\section{Introduction}

The demand for water and energy has been raising continuously and their shortage has resulted in the development of alternative renewable energies and water treatment systems which require less energy. Two of the osmotically driven membrane processes (ODMPs), namely forward osmosis (FO) and pressure retarded osmosis (PRO), have attracted the most attention in the past years as 
the emerging technologies for numerous applications such as wastewater treatment and biomass processing for bioenergy [1].

Osmosis refers to the movement of solvent molecules mostly water from the feed solution (FS) which has lower solute concentration into draw solution (DS) which has higher solute concentration across a semipermeable membrane. The osmotic pressure difference $(\Delta \pi)$ between the two solutions is the driving force for ODMPs and the same quantity of hydraulic pressure is required to terminate the osmosis process. In contrast, pressure-driven membrane processes (e.g., nanofiltration, $\mathrm{RO}$, etc.) rely on externally applied hydraulic pressure [2]. The key benefits of ODMPs compared to the latter are that they consume less energy and have lower fouling tendency, which results in high water flux, high rejection of salt, and less membrane cleaning [3].

FO processes occur without any applied hydraulic pressure $(\Delta \mathrm{P}=0)$ [4]. Once the solvent starts moving from FS to DS, the hydrostatic pressure on the DS side gradually becomes greater and the water flow will stop eventually; mathematically, the water flux (Jw) stops when $\Delta \mathrm{P}$ equals to $\Delta \pi$ (where $\Delta \pi-\Delta \mathrm{P}=0$; hence Jw $=0$ ) [5]. On the other hand, reverse osmosis $(\mathrm{RO})$ employs hydraulic pressure differential as its driving force to move water from the saltwater to the freshwater, resulting in a negative flux across the membrane. This occurrence is relatively due to the large pressure $(\Delta \mathrm{P}>\Delta \pi)$ exerted to the concentrated side.

PRO processes are intermediate between $\mathrm{FO}$ and RO. Similar to RO, hydraulic pressure is applied to the DS side against the osmotic pressure gradient, but it is smaller than the osmotic pressure difference $(\Delta \mathrm{P}<\Delta \pi)$. Thus, the net water flux, $\mathrm{J}_{\mathrm{W}}$ is still towards concentrated $\mathrm{DS}$, which is in a similar direction as FO [4]. To generate the power steadily, a constant concentration and pressure must be set for the DS so that a constant flow of FS across the membrane can occur. Subsequently, there is more volume flow on the concentrated region and this additional flow can be employed for power generation regarding bioenergy production [5].

There are several differences between FO and PRO in terms of the fundamentals and applications, even though both processes utilize a similar driving force, which is salinity gradient difference [6]. For instance, FO processes are employed to produce clean water, dilute draw solution, or concentrate feed solution in applications including brine treatment and desalination [2]. On the other hand, PRO processes are employed to generate electricity or power using osmotic pressure from the DS. The application difference is caused by the fundamental difference in their operations as FO processes involve direct use of osmotic pressure to transport less concentrated solution across semipermeable membrane barrier while PRO processes utilize hydraulic pressure to pressurize the DS to help in converting the osmotic pressure to hydraulic pressure [7].

Besides PRO processes with power generation as the main application, FO processes can be integrated with other systems for bioenergy production. For instance, bioenergy from organic matter found in wastewater can be converted into electricity via forward osmosis-bioelectrochemical hybrid systems (FO-BESs) which use electrochemically active bacteria [8]. One example of FO-BESs is osmotic microbial fuel cell (OsMFC) which separates anode and cathode with an FO membrane. It produces more electricity compared to the conventional microbial fuel cell with a cation exchange membrane [9]. Moreover, energy recovery (e.g., biogas production) can be carried out through an anaerobic osmotic membrane bioreactor (An-OMBR) which integrates $\mathrm{FO}$ with anaerobic treatment by submerging an $\mathrm{FO}$ membrane inside the bioreactor. FO processes can be used to concentrate nutrients and harvest algae which is a bioenergy source, where biodiesel can be produced from its lipid extract and bioethanol can be fermented from its carbohydrates [10,11].

Although there are several ODMPs applications for bioenergy production, these processes are so far applied in lab-scale studies only and up-scaling to full scale is essential. To achieve at that stage, optimization of process parameters has to be investigated. Therefore, this paper comprehensively reviews the factors influencing the performance of the ODMPs, which is generally measured by water flux, reverse solute flux, and power density. Various aspects of an osmotic membrane such as concentration polarization, membrane materials, membrane configurations, and fouling are discussed. 
The next sections focus on the feed solutions and draw solutions which provide the osmotic pressure difference to drive the ODMPs. Operating conditions including cross-flow rate and temperature are also studied for their effects on the performance of FO and PRO. This review provides insights into the concerned researches in practically designing an optimum osmotic membrane system for bioenergy production.

\section{Osmotic Membrane}

During the past 40 years, membrane development has been focused on pressure driven processes but the attention in ODMPs, like FO and PRO, has increased in the last decade [12] since they demonstrate significant promise to leverage the global water-energy nexus [13]. It is crucial to formulate customized membranes for these technologies since membrane properties such as structural parameters, water permeability and solute permeability affect the overall performance of FO and PRO processes. For instance, asymmetric FO membrane is an essential component to determine the performance of FO-BES where its properties such as mass transfer resistance and proton transfer ability affect the bioenergy production [8]. Generally, there are two methods to prepare membrane including (1) direct phase inversion, which involves phase inversion of a polymer dope in a non-solvent followed by formation of integrally skinned membranes, and (2) interfacial polymerization (IP), which is utilized to create thin-film composite (TFC) membranes [14]. Modifications on membrane including its microporous substrate and selective layer have been the main research area to improve the performance of FO and PRO processes. For instance, specific functional compounds or groups have been introduced on the surface of the selective layer to tackle the problems of fouling and low productivity [15]. In short, a desired osmotic membrane should be thin, highly selective, and antifouling while compatible with the chosen draw solution, produce high water fluxes, decline dissolved solutes, and tolerate mechanical pressures caused by operation conditions $[15,16]$.

\subsection{Concentration Polarization}

An osmotic membrane consists of an active layer and a support layer. The former selectively allows movement of solvent molecules but declines at least some dissolved ions whereas the latter with a side bond to the former comprises a phase-inversion sub-layer and an electrospun-fiber sub-layer. Concentration polarization (CP) happens when the salt concentration difference across the active layer is different from the concentration difference of the bulk solutions itself [17]. Since DS is diluted by the incoming water flux, there is an immediate reduction in the osmotic pressure at the surface of membrane facing the concentrated DS, causing the solute concentration on the other membrane side facing the FS to increase, since the diffusion of water is towards the DS [18].

Depending on the membrane orientation, these two $\mathrm{CP}$ phenomena can happen either on the active layer or on the support layer since the asymmetric membrane is used in the FO process. Although any of the membrane orientations can be used to operate ODMPs, for clarity, the process is said to be in FO mode (also known as AL-FS orientation) given that the active layer faces FS and support layer faces DS. Generally, this mode can be used for any membrane separation process. In contrast, the process is termed as PRO mode (also known as AL-DS orientation) when the active layer faces the DS and the support layer faces the FS. PRO mode is normally used for osmotic power generation [19].

On the other hand, there are two kinds of $\mathrm{CP}$ where the formation of a concentration layer at the membrane surface and in the porous structure of asymmetric membranes is defined as external concentration polarization (ECP) and internal concentration polarization (ICP), respectively [20]. ECP is usually associated with the concentrations of DS and FS whereas ICP is mainly affected by the support layer structure and thick dense membrane [4]. The presence of $\mathrm{CP}$ can significantly affect the effective osmotic pressure difference $(\Delta \pi)$ across the membrane leading to a sharp decline in water flux and operational performance of FO and PRO processes [21,22].

In PRO mode operation, water from FS moves into the porous support layer and permeates through the active layer. The salt from FS also enters the support layer however, it cannot pass through 
the active layer, resulting in an increase of concentration within the support layer, which is called concentrative ICP. In FO mode operation, dilutive ICP takes place when water permeate dilutes the DS within the porous support layer, causing slow solute mass transfer [23]. ICP could become acute in ODMPs and it cannot be erased by manipulating hydraulic conditions like increasing turbulence or shear force since it happens within the support layer, thus membranes specially designed for ODMPs are desired for applications [2]. Optimization on porosity, thickness, and tortuosity of the substrate structure is essential for minimizing the severe effects of ICP. For example, an FO membrane that has a highly porous substrate with low tortuosity and a detect-free thin selective layer is the most effective approach to alleviate ICP [15].

\subsection{Membrane Materials}

To develop a system with optimal flux, the choice of material to fabricate a membrane is significant because membrane fouling can directly affect the membrane flux. The material selection also depends on the purpose of the membrane since the operational parameters of FO and PRO are quite different. They require different selectivity degrees for the membrane skin layer where FO needs highly selective membranes whereas PRO which targets high power density requires just sufficient salt decline to maintain the driving force and govern concentration polarization [24]. Furthermore, most conventional FO membranes, which are usually tailored to be porous and thin to lower ICP and structural parameters, will either be damaged or deformed under high pressure of PRO [14]. This may cause serious leakage of DS and failure towards the entire process [25]. This indicates that PRO membranes must be robust enough to tolerate the operational hydraulic pressure. Micro-void type support layers that tend to reduce $\mathrm{CP}$ can be beneficial for the FO process; however, their applications in $\mathrm{PRO}$ are restricted to lower pressure processes since the micro-void structure can easily be collapsed under the effects of high hydraulic pressure [26].

Early attempts to fabricate FO and PRO specialized membranes were restricted to cellulose triacetate (CTA) and TFC membranes [25]. Cellulose is the most abundant existing natural polymer and derivatives of cellulose such as cellulose acetate (CA) and CTA are appropriate materials to fabricate membranes due to their good separation, moderate flux, and non-toxicity [27]. In order to produce CTA membranes (as demonstrated in Figure 1A), a dense active layer is formed by casting CTA with an embedded polyester fabric where the thickness of the active layer is minimized to improve the water permeability while maintaining the membrane integrity or contaminant rejection [15]. However, CTA membranes have restrictions in their application for desalination due to their comparatively low water permeability and solute rejection. Severe $\mathrm{CP}$ has been induced in CTA membranes by a sponge-like structure which was initially designed to improve flux [15]. In addition, cellulose-based materials not only have low stability to $\mathrm{pH}$ and temperature but also undergo biodegradation and hydrolysis [27].

Therefore, enhanced TFC membranes have been developed to keep the high water flux obtained by CTA membranes and to improve the mechanical robustness of the membranes [25]. This is because highly selective and permeable TFC membranes have high flexibility in structural design with the ability to individually optimize the two membrane layers (selective and substrate layer) for specific needs $[15,28]$. Modification on the structure of the support layer significantly reduces ICP while having the dense thin film layer allows great water permeability and salt rejection [7]. A TFC membrane (as shown in Figure 1B) generally consists of (1) a very thin polyamide active layer, (2) a polymeric support layer, and (3) a fabric layer for mechanical support [29]. Some examples of the artificial polymers are polysulfone (PSF), polyether sulfone (PES), polyvinylidene fluoride (PVDF) and polyacrylonitrile (PAN) [27]. The standard preparation method of TFC membrane layer-by-layer assembly using the microporous substrate obtained through phase inversion and the polyamide layer formed through IP between chloride and amine monomers such as trimesoyl chloride and m-phenylenediamine [15]. 

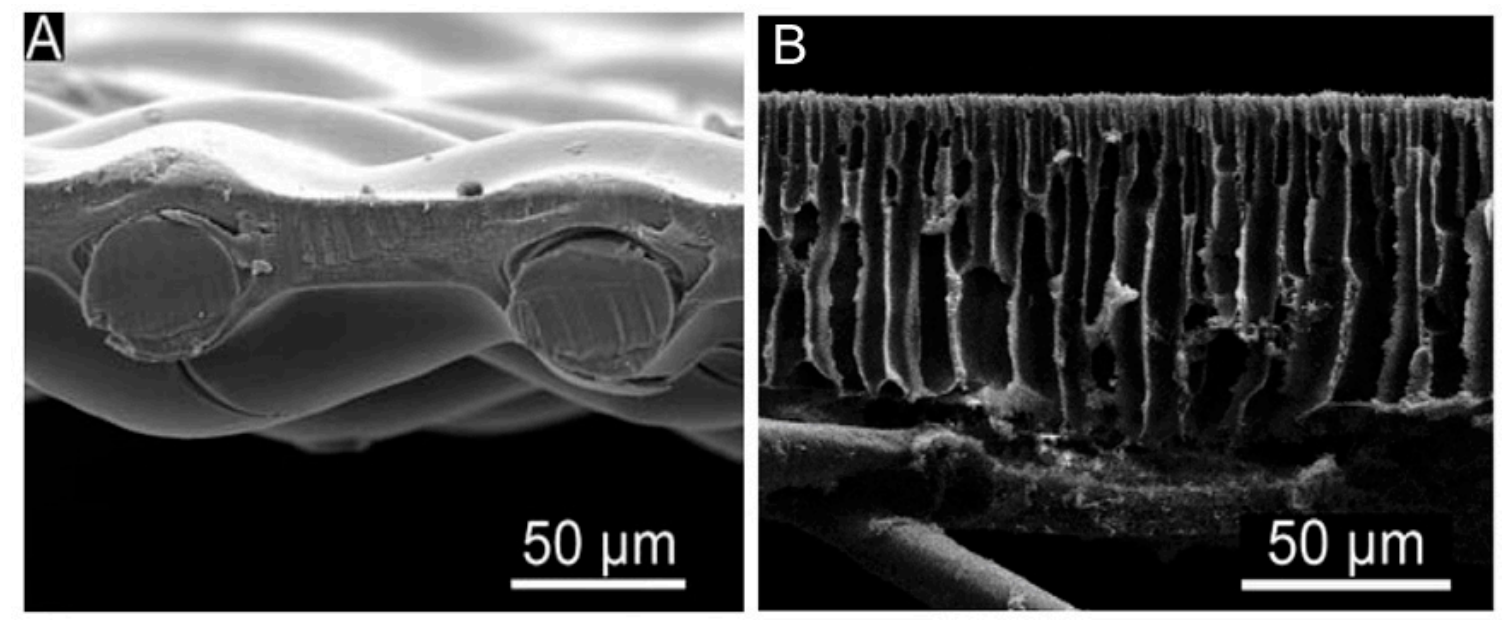

Figure 1. Cross-section SEM micrographs of (A) commercial CTA-HTI and (B) TFC membrane. Reproduced with permission from Yip, Tiraferri, Phillip, Schiffman and Elimelech [16], Copyright (1969) American Chemical Society.

Wang, et al. [30] had compared the characteristics of CTA and TFC FO membranes provided by Hydration Technologies Innovation (HTI, Albany, NY, USA) and the results are shown in Table 1. The smaller contact angles indicate a higher hydrophilicity degree, which means permeation of water is easier and higher water flux is expected [31]. Indeed, higher water flux was observed in TFC membrane compared to CTA membrane under the same operating conditions [30]. It is noteworthy that in a more recent study by $\mathrm{Li}$, et al. [32], a self-made TFC membrane in comparison with a commercial CTA-HTI membrane also exhibited higher flux loss due to membrane fouling [32]. Flux loss is one of the important criteria to be considered for overall flux performance when designing an osmotic membrane system. Nevertheless, higher reverse salt flux was observed with TFC membranes in both studies [30,32].

Table 1. Comparison of commercial CTA and TFC membrane produced by Hydration Technologies Innovation (HTI, Albany, NY, USA). Adapted with permission from Wang, Tang, Zhu, Dong, Wang and $\mathrm{Wu}[30]$, Copyright (2014), Elsevier B.V.

\begin{tabular}{ccc}
\hline Parameters & Cellulose Triacetate & Thin-Film Composite \\
\hline Thickness of active layer $(\mu \mathrm{m})$ & $6.1 \pm 2.0$ & $4.9 \pm 1.1$ \\
Thickness of support layer $(\mu \mathrm{m})$ & $51.4 \pm 6.7$ & $47.8 \pm 2.5$ \\
Pore size of SL $(\mu \mathrm{m})$ & $5.3 \pm 1.0$ & $3.9 \pm 2.0$ \\
Contact angle of active layer $\left(^{\circ}\right)$ & $86.0 \pm 4.5$ & $79.2 \pm 6.3$ \\
Contact angle of support layer $\left(^{\circ}\right)$ & $72.8 \pm 1.9$ & $73.8 \pm 6.0$ \\
Water permeability $(\mathrm{A})\left(\mathrm{L} /\left(\mathrm{m}^{2} \mathrm{~h}\right.\right.$ bar $\left.)\right)$ & $0.70 \pm 0.07$ & $1.24 \pm 0.04$ \\
Salt permeability $(\mathrm{B})\left(\mathrm{L} /\left(\mathrm{m}^{2} \mathrm{~h}\right)\right)$ & $0.53 \pm 0.03$ & $0.37 \pm 0.08$ \\
Salt rejection rate $(\%)$ & $94.7 \pm 0.1$ & $97.7 \pm 0.5$ \\
Water flux & Lower & Higher \\
Reverse solute flux & Lower & Higher \\
\hline
\end{tabular}

In another study [33], which compared the PRO performance of five different membranes including CTA-HTI, CTA-HTI spiral, CTA-FTS, TFC-FTS, and TFC-Aquaporin (Fluid Technology Solutions (FTS) and Aquaporin A/S are commercial membrane companies), it was found that although TFC membranes have higher flux, CTA membranes with higher pressure stability show higher power densities because the latter with a thicker rejection layer is less likely to be damaged at high pressure while the former is more prone to compaction. To summarize, it is obvious that each material has better performance in different aspects and more comparison studies should be carried out to provide evidence that support the hypothesis of one being better than another. 
The development of the membrane materials and synthesis methods has been enhanced by the research and commercial attention on FO and PRO, resulting in the use of other materials [25]. For instance, a variety of nanomaterials, as shown in Table 2, has been used to alter the membrane substrates, either only form the active layer, or fabricate the whole thin film nanocomposite (TFN) membranes [34]. Incorporation of hydrophilic nanomaterials such as carbon-based nanomaterials functionalized with hydrophilic moieties can alleviate ICP by forming higher hydrophilicity, bigger porosity, and lower tortuosity [35]. Since the synthesis processes for TFC membranes are well established, any discovery on new membrane materials can be scaled up effortlessly for commercialization [36]. For example, aquaporins, which are water channel membrane proteins, have been incorporated into membrane substrate and this biomimetic Aquaporin membrane has been large scale commercialized for academic and industrial applications [37]. Nonetheless, it must be noted that there is a limited number of pilot-scale research carried out to apply TFC membranes in commercial-scale FO and PRO processes. More extensive researches at a bigger scale are needed for osmotic membranes to find out their feasibility for a sustainable operation to the point of commercialization despite the promising findings in laboratories.

Table 2. Recent nanostructured osmotic membrane and their experimental performance.

\begin{tabular}{|c|c|c|c|c|c|}
\hline \multirow{2}{*}{$\begin{array}{c}\text { Type of } \\
\text { Nanomaterials }\end{array}$} & \multirow{2}{*}{$\begin{array}{l}\text { Nanoparticles } \\
\text { Incorporated }\end{array}$} & \multirow{2}{*}{ Effects } & \multicolumn{2}{|c|}{ Water Flux $\left(J_{w}, L / m^{2} h\right)$} & \multirow{2}{*}{ Ref. } \\
\hline & & & Unmodified & Incorporated & \\
\hline $\begin{array}{l}\text { Carbon } \\
\text { nanotubes }\end{array}$ & $\begin{array}{l}400 \text { ppm sulfonated } \\
\text { carbon nanotubes }\end{array}$ & $\begin{array}{ll}\text { - } & \text { Better } \\
\text { - } & \text { separation performance } \\
\text { - } & \text { Entter permselectivity } \\
\text { - } & \text { Decreased } \\
& \text { surface roughness }\end{array}$ & $21.3 \pm 2.1$ & $29.9 \pm 1.6$ & $\begin{array}{l}\text { Li, et al. } \\
{[38]}\end{array}$ \\
\hline Zeolites & $\begin{array}{l}0.4 \mathrm{wt} \% \text { modified } \\
\text { clinoptilolite }\end{array}$ & $\begin{array}{ll}\text { - } & \text { Increased } \\
\text { membrane porosity } \\
\text { - } & \text { Higher eccentricity } \\
\text { - } & \text { Reduced structural } \\
& \text { parameter (S) } \\
\text { - } & \text { Minimized ICP }\end{array}$ & 16.3 & 24.61 & $\begin{array}{l}\text { Salehi, et } \\
\text { al. [39] }\end{array}$ \\
\hline Zwitterions & $\begin{array}{c}\text { Poly [3-(N-2-methacry } \\
\text { loylxyethyl- } \\
\text { N,N-dimethyl)- } \\
\text { ammonatopropan } \\
\text { esulfonate] (PMAPS) }\end{array}$ & $\begin{array}{ll}\text { - } & \text { Lower water } \\
\text { contact angle } \\
\text { - } & \text { Enhanced hydrophilicity } \\
\text { - } & \text { Remarkable } \\
\text { anti-fouling properties }\end{array}$ & 12.54 & 15.79 & $\begin{array}{l}\text { Lee, et al. } \\
\text { [40] }\end{array}$ \\
\hline $\begin{array}{l}\text { Graphene } \\
\text { oxide }\end{array}$ & $\begin{array}{l}0.1 \% \text { graphene oxide } \\
\text { nanosheets }\end{array}$ & $\begin{array}{ll}\text { - Increase in } \\
\text { the hydrophilicity } \\
\text { - } \quad \text { Increase in a surface } \\
\text { roughness value } \\
\text { - } \quad \text { Better water permeability }\end{array}$ & 7.9 & 14.5 & $\begin{array}{c}\text { Shokrgozar } \\
\text { Eslah, et } \\
\text { al. [41] }\end{array}$ \\
\hline $\begin{array}{c}\text { Carbon } \\
\text { quantum dots }\end{array}$ & $\begin{array}{l}\mathrm{Na}^{+} \text {-functionalized } \\
\text { carbon quantum dots }\end{array}$ & 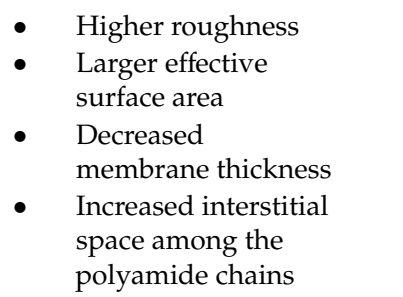 & $24.25 \pm 2.8$ & $34.86 \pm 1.41$ & $\begin{array}{l}\text { Gai, et al. } \\
\text { [42] }\end{array}$ \\
\hline
\end{tabular}


Table 2. Cont.

\begin{tabular}{|c|c|c|c|c|c|}
\hline \multirow{2}{*}{$\begin{array}{c}\text { Type of } \\
\text { Nanomaterials }\end{array}$} & \multirow{2}{*}{$\begin{array}{l}\text { Nanoparticles } \\
\text { Incorporated }\end{array}$} & \multirow{2}{*}{ Effects } & \multicolumn{2}{|c|}{ Water Flux $\left(J_{w}, L / m^{2} h\right)$} & \multirow{2}{*}{ Ref. } \\
\hline & & & Unmodified & Incorporated & \\
\hline $\begin{array}{l}\text { Metal and } \\
\text { metal oxide } \\
\text { nanoparticles }\end{array}$ & $\begin{array}{c}0.5 \mathrm{wt} \% \text { molybdenum } \\
\text { oxide NPs } \\
\left(\mathrm{MoO}_{3}\right)\end{array}$ & $\begin{array}{l}\text { - } \quad \text { Increased wettability } \\
\text { Enhanced surface } \\
\text { roughness, } \\
\text { hydrophilicity, and } \\
\text { water permeability }\end{array}$ & $\sim 21$ & 67 & $\begin{array}{l}\text { Amini, et } \\
\text { al. [43] }\end{array}$ \\
\hline Polyelectrolytes & $\begin{array}{c}\text { Layer-by-layer } \\
\text { polyvinylidenefluoride } \\
\text { (PVDF) }\end{array}$ & $\begin{array}{l}\text { - Enhanced hydrophilicity } \\
\text { and porosity } \\
\text { - } \quad \text { High pure } \\
\text { water permeability } \\
\text { - Low } \\
\text { structural parameter }\end{array}$ & 5.4 & 24.1 & $\begin{array}{l}\text { Gonzales, } \\
\text { et al. [44] }\end{array}$ \\
\hline $\begin{array}{l}\text { Metal-organic } \\
\text { frameworks }\end{array}$ & $\begin{array}{l}0.12 \mathrm{w} / \mathrm{v} \% \text { copper } \\
\text { 1,4-benzenedicarboxylate } \\
\text { nanosheets, } \\
\text { CuBDC-NS }\end{array}$ & $\begin{array}{ll}\text { - } & \text { Reduced contact angles } \\
\text { Increased } \\
\text { - } & \text { Murface hydrophilicity } \\
\text { Much lower reverse } \\
\text { solute flux }\end{array}$ & 18 & 28 & $\begin{array}{c}\text { Dai, et al. } \\
\text { [45] }\end{array}$ \\
\hline
\end{tabular}

\subsection{Membrane Configurations}

In addition to membrane materials, membranes have been fabricated into two membrane configurations based on geometry that is flat sheet and hollow fiber configurations to improve performance such as achieving high water fluxes and superior rejection properties [46]. Generally, as compared to the hollow fiber membrane, it is easier to engineer a thinner support layer in a flat sheet membrane, thus it has higher water flux and power density [7]. However, due to the thin support layer and lower packing density, flat sheet membranes are less mechanically stable and more likely to experience structural destructions under pressure, even with a macro-void free support layer [14]. Compaction due to pressure always negatively affects the properties of the flat sheet membranes, such as increasing the resistance of porous substrates, decreasing the permeability of the selective layers, and enhancing the salt leakage by spacer [47].

Therefore, recent approaches in developing flat sheet membranes focus on enhancing their mechanical robustness, which is crucial for the PRO applications since it decides the maximum applicable hydraulic pressure. For example, the selective layer of flat sheet membranes is normally post-treated with chemical and physical modification for better mechanical strength [48]. Another approach to improve the pressure tolerance of flat sheet membranes is by utilizing customized spacers. Membrane with customized tricot fabric spacers was able to tolerate a stable 48 bar hydrostatic pressure for exceeding $10 \mathrm{~h}$ and achieve $14.1 \mathrm{~W} / \mathrm{m}^{2}$ at 20.7 bar [14]. The restrictions of pressure observed in numerous previous $\mathrm{PRO}$ research are primarily because of the unsuitable selection of spacer material.

Hollow fiber membranes (as shown in Figure 2) are tubular-shaped membranes and this configuration provides key benefits including a self-supporting structure and high packing density in membrane modules [49]. Hollow fiber membranes commonly feature a higher mechanical strength due to their geometrical (circular) structure. The fabric support-free hollow fiber configurations could also give rise to better control of the structural parameters [49]. Furthermore, the hollow fiber membrane module demonstrates higher efficiency (flux) of mass transfer compared to the flat-sheet (spiral-wound) module [50]. Wang, et al. [51] discovered that contact angles of FO hollow fiber membranes were much smaller than the commercial flat sheet membranes suggesting that they have higher hydrophilicity and lower fouling tendency. Besides, Chou, Wang and Fane [47] reported much 
lower specific reverse salt flux in the hollow fiber membrane as its self-supporting structure can eliminate the deformation-enhanced reverse solute flux which is common for flat-sheet membranes.

\section{Shell side}

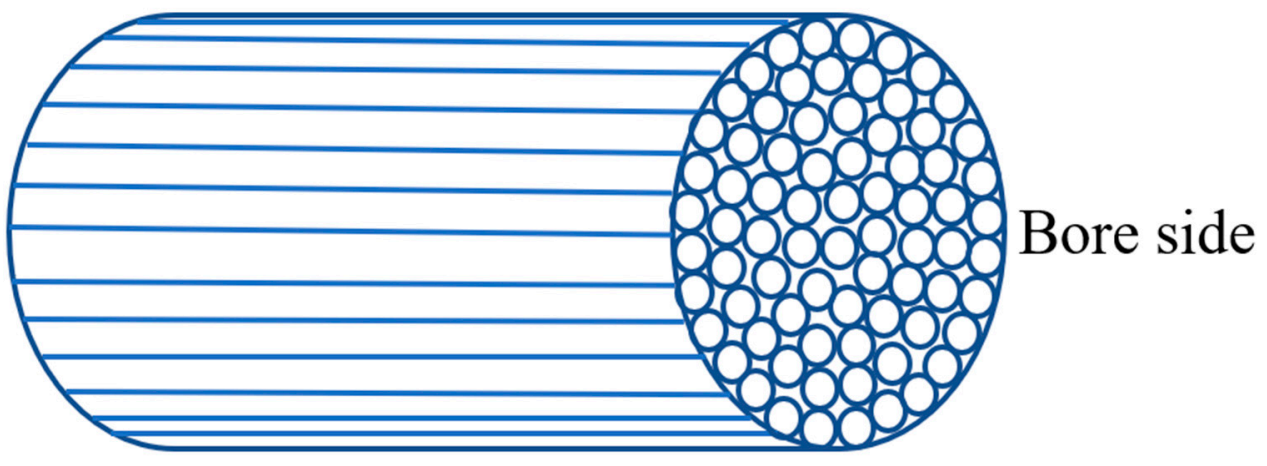

Figure 2. Hollow fiber membranes.

Moreover, hollow fiber membranes do not require spacers to effectively support the flowing of liquids on both sides of the membranes. Without spacers, deformation of the membrane caused by the spacer under high pressures could be minimized and more membranes could be packed into the modules. Also, with a self-supporting structure, higher pressures can be achieved by keeping the pressurized DS on the shell side rather than on the bore side of the fiber [52]. Since a spacer is not required in hollow fiber membranes with DS on the shell side, power density can be improved without the potential energy loss from the interface between membrane and spacer [53]. The Japanese Mega-ton project had tried a prototype by modifying and upscaling CTA-based RO hollow fiber membrane into PRO membrane module and achieved a power density of $7.7 \mathrm{~W} / \mathrm{m}^{2}$ at 25 bar [54]. However, they usually have smaller initial water flux compared to the flat sheet membranes (before deformation takes place), and they are likely to face pressure drop problems within each hollow fiber [6]. In addition, increasing pressure causes a reduction in the dimensions of fiber, leading to an increase in feed pressure loss on the bore side [52]. These are research gaps that researchers can look into so that there will be an enhancement in hollow fiber membranes and the performance of ODMPs.

Power density is a significant parameter in selecting the membrane for the PRO process. Although increasing the membrane area can scale up the energy generation, membranes with high power density which produce greater power per unit area reduce the membrane size required and the capital cost. As demonstrated in Table 3, various enhanced hollow fiber TFC membranes have been developed recently and applied in PRO processes where the highest power density in the literature so far is $38 \mathrm{~W} / \mathrm{m}^{2}$. In contrast, there is limited literature on the application of flat sheet membranes in osmotic power generation recently, after Han et al. [14] had summarized PRO performance of TFC flat sheet membranes up to 2015. One of the recent studies is research by Sharma, et al. [55] which discovered that CA flat sheet membrane modified with PEG 6000 achieved power density of $3.1 \mathrm{~W} / \mathrm{m}^{2}$. In brief, flat sheet membranes are more appropriate for FO applications due to their highly engineered support layer while hollow fiber membranes that have simple fabrication, high-pressure resistant structures, and high membrane surface area per module are comparatively suitable to harvest energy through PRO process [25]. 
Table 3. PRO performance of recent hollow fiber membranes.

\begin{tabular}{cccccc}
\hline Membrane & Feed Solution & Draw Solution & $\begin{array}{c}\text { Hydraulic } \\
\text { Pressure (Bar) }\end{array}$ & $\begin{array}{c}\text { Power Density } \\
\left(\mathbf{W} / \mathbf{m}^{\mathbf{2}}\right)\end{array}$ & Ref. \\
\hline TFC & DI water & $1.2 \mathrm{M} \mathrm{NaCl}$ & 30 & 38 & Wan, et al. [56] \\
TFC & DI water & $1 \mathrm{M} \mathrm{NaCl}$ & 16.5 & 14.6 & Park, et al. [57] \\
TFC & DI water & $0.81 \mathrm{M} \mathrm{NaCl}$ & 20 & 18.8 & Zhang, et al. [58] \\
TFC & DI water & $1.0 \mathrm{M} \mathrm{NaCl}$ & 20 & 12.1 & Gonzales, et al. [59] \\
TFC & DI water & $1 \mathrm{M} \mathrm{NaCl}$ & 21 & 16.7 & Lim, et al. [60] \\
TFC & DI water & $1 \mathrm{M} \mathrm{NaCl}$ & 20 & 20 & Wan, et al. [61] \\
TFC & DI water & $1 \mathrm{M} \mathrm{NaCl}$ & 20 & 27 & Wan and Chung [62] \\
\hline
\end{tabular}

\subsection{Membrane Fouling}

Membrane fouling, which happens due to the deposition of particles and/or solutes at the membrane surface or inside membrane pores, is one of the main factors influencing membrane performance in ODMPs [12]. There are four types of fouling and their respective model foulants are shown in Table 4. The chemical and hydrodynamic interactions between the foulants and the membrane surface either temporarily or permanently decrease membrane water flux [63], leading to lowered permeate quality, reduced water recovery, shortened membrane life, and increased operating cost [13]. This is because foulants not only react with the membrane surface physically but also deteriorate membrane material chemically [63]. In addition, the accumulation of foulant influences power density used to generate energy in PRO. A layered model by Nagy, et al. [64] demonstrated a $50 \%$ reduction of power production due to a $500 \mu \mathrm{m}$-thick cake layer.

Table 4. Fouling types and model foulants.

\begin{tabular}{cc}
\hline Type of Fouling & Model Foulants \\
\hline Organic & Alginate, humic acid (HA), and bovine serum albumin (BSA) \\
Inorganic & Calcium salts and silica \\
Colloidal & Colloidal silica particles \\
Biological & Escherichia coli bacteria suspensions \\
\hline
\end{tabular}

A lot of academic studies, industrial researches and development efforts have been carried out since the early 1960s to mitigate membrane fouling [63], which is influenced by various factors such as operation conditions, membrane properties, level of pretreatment and solution chemistry [21]. The properties and characteristics of membranes that influence fouling formation are their morphology (i.e., surface roughness, surface pattern, or pore size) and chemical structure (i.e., charge, hydrophilicity, and functional groups). In general, low surface roughness, high hydrophilicity, and negative surface charge are desirable [65].

In ODMPs, the accumulation of foulants takes place on different surfaces of membrane depending on the membrane orientation, hence fouling can be categorized into internal and external fouling [66]. In FO mode, foulants are accumulated on the relatively smooth active layer and a cake-type layer is subsequently formed. The deposition of foulants is influenced by both shear force and permeation drag, resulting from bulk cross-flow and permeate flux, respectively [67]. This manner of fouling is referred to as external fouling.

The mechanism of fouling is more complex in PRO mode. The foulants which are relatively small compared to the pores of the rough support layer can enter the membrane porous support layer and be adsorbed on the walls, or eventually be retained by the dense active layer and deposited at the back of the active layer. Subsequently, foulants which penetrate the support layer attached to the foulants which have been accumulated on the active layer, resulting in clogging of the membrane pores. This is the most serious case of fouling and is very difficult to clean up [68]. At the beginning of fouling in PRO mode, the effect of hydrodynamic shear forces is absent since cross-flow velocity disappears within 
the support layer [67]. Fouling in this manner is called internal fouling. Under severe conditions of fouling, more foulants continue to accumulate outside of the support layer, resulting in both external and internal fouling [66].

External fouling, in comparison with internal fouling, happens on the surface of the membrane so it is more able to be removed and reversed via optimizing feed water hydrodynamic conditions or chemical cleaning [69]. Therefore, AL-FS orientation is recommended by most researchers for FO application to avoid unwanted internal fouling [70], although there is relatively higher water flux in PRO mode since crossflow shear on the membrane surface can mitigate dilutive ECP [18]. On the other hand, PRO membranes are usually in operation of PRO mode due to higher mechanical stability (to avoid rejection layer damage) and higher power density (in the absence of fouling) [71].

Even though the osmotic backwash method has been developed to clean foulants within the support layer [72], it is essential to develop internal fouling control which is more effective for PRO because the requirement of pretreatment of feed water and membrane cleaning increases energy consumption and incurs additional costs [73]. It is also urgent to develop an appropriate PRO membrane to mitigate support layer fouling where material and roughness of the surface of the support layer should be taken into account [12]. Nevertheless, it should be clarified that both internal and external fouling can be irreversible depending on feed water constituents and their interactions with the membrane [74].

\section{Feed Solutions}

A variety of FSs, such as sewage [75,76], grey water [77], and microalgae [76,78], have been examined for their feasibility in different FO applications. Study on these commercially available FSs and other unexplored FSs is very important to understand their applicability, sustainability and economic feasibility in FO processes. Since FO is driven by the osmotic pressure difference, increasing feed concentration leads to lower initial flux due to the higher osmotic pressure of FS followed by a thinner foulant layer due to lowered convection of foulants to the membrane [64]. Furthermore, the presence of salt in the FS increases ICP in the membrane and reduces the achievable power density. Madsen et al. [33] reported a $55 \%$ reduction in power density $\left(8 \mathrm{~W} / \mathrm{m}^{2}\right.$ to $\left.3.6 \mathrm{~W} / \mathrm{m}^{2}\right)$ when FS was changed from MilliQ ultrapure water to a $2 \mathrm{wt} \% \mathrm{NaCl}$ solution. The reduction in power density was not linear and the biggest difference occurred when changing MilliQ water to $0.01 \mathrm{wt} \%$, which is the typical salinity of the river water model. This indicates that the suitability of river water as a FS should be investigated and DS with higher salinity should be studied to generate higher power. Moreover, the presence of other solutes (either dissolved or suspended) in FS could directly influence the FO performance [18]. This is because an increase in total dissolved solids of FS results in a reduction of net osmotic pressure, thus reducing water flux [18]. Composition and chemistry of FS-including the availability and concentration of divalent ions, ionic strength, and $\mathrm{pH}$-strongly affect the fouling behavior in FO since characteristics of the foulants (e.g., membrane surface charge) and the foulant-foulant and foulant-membrane interactions are influenced [79]. For instance, comparatively high retention of ammonia was observed at a $\mathrm{pH}$ of 5 and the retention gradually decreased when the $\mathrm{pH}$ increased. Meanwhile, there was an enhancement in the retentions of nitrite, nitrate, and phosphate when $\mathrm{pH}$ was increased from 5-8. This is because the electrostatic repulsion between the membrane and the negatively charged ions was strengthened by the increasing negative charge on the surface of the membrane [76].

Feed waters with different qualities have been researched to determine the major foulants since water flux and osmotic power generation are reduced by membrane fouling, making the overall cost as high as other membrane processes [80]. In addition, for certain quick fouling, high cleaning frequency and long downtime processing are required making the conventional backwash approaches impractical. Also, adding a large amount of chemicals that are expensive to alleviate fouling in PRO processes is not viable economically [81]. 


\section{Pretreatments}

In order to reduce membrane fouling and to improve the performances, various pretreatment approaches-including microfiltration [82], vacuum filtering [83], low-pressure nanofiltration [84], low-pressure reverse osmosis [81], and coagulation [85] — have been investigated. Water flux increases when pretreatment is carried out since the suspended solids in feed solution are removed. However, Yang, Gao, Jang, Shon and Yue [83] reported that the increment associated with sewage pre-filtration decreased with time. Seker, et al. [86] presented similar findings where initial water flux with pretreatment $\left(8.5 \mathrm{~L} / \mathrm{m}^{2} \mathrm{~h}\right)$ was lower but water flux of pretreated whey decreased slowly and final flux $\left(4 \mathrm{~L} / \mathrm{m}^{2} \mathrm{~h}\right)$ was the same as the flux of non-pretreatment. Therefore, it should be noted that pretreatment only delays, but does not mitigate, the fouling formation.

In addition, the power density increases after the pretreatment. Results shown by Yang, Wan, Xiong and Chung [81] demonstrated that the PRO process without pre-treatment at 15 bar generated a power density of $2.92 \mathrm{~W} / \mathrm{m}^{2}$ (only $40 \%$ of its initial power density) while the PRO process using filtrates from nanofiltration could produce a stable power density of $7.3 \mathrm{~W} / \mathrm{m}^{2}$ with only a $10.7 \%$ drop. Nonetheless, Kim and Kim [87] suggested omitting pretreatments in designing and operating PRO because pretreatments need more energy $\left(0.1-0.4 \mathrm{kWh} / \mathrm{m}^{3}\right)$ than the extractable net energy $\left(0.1 \mathrm{kWh} / \mathrm{m}^{3}\right)$ and net energy extraction from seawater and river water could be done using PRO even with severe fouling. Therefore, an economical and less energy-intensive approach should be developed for pretreatments, otherwise pretreatments might not be that helpful in both FO and PRO processes.

\section{Draw Solutions}

Identifying an appropriate draw solute/solution is one of the major challenges to the $\mathrm{FO}$ and PRO processes. Since the mid-1960s, a variety of DS has been proposed and examined to maximize the efficiency of these processes but none of them have been successful for commercialization [88]. There are several important criteria to be fulfilled by an ideal DS, which are (i) high water flux (high osmotic pressure), (ii) simple and cheap recovery from the diluted DS, and (iii) low reverse solute flux (RSF) [89]. However, the first two requirements are in fact a conflict between one another since good osmotic potential requires a strong association between water molecules and draw solutes, which subsequently complicates the recovery process [90]. The recovery of DS remains one of the main challenges even though various approaches have been proposed including $\mathrm{RO}$, heating/distillation, ultrafiltration, nanofiltration, magnetic separation, physical triggers, precipitation, and membrane distillation [91].

There are various additional criteria for an ideal draw solute, such as having no damage, scaling or fouling on the membrane surface even after prolonged use, intrinsic properties (e.g., at or near neutral $\mathrm{pH})$, low viscosity even at high concentrations, low toxicity without adverse effect on environment and human health, a high diffusion coefficient to reduce ICP, being chemically stable for repeated use as well as cost-effective [91]. However, some contradictions between or deviations to some of these criteria may exist. For instance, solutes with small size like $\mathrm{NaCl}$ are more likely to achieve a high diffusion coefficient which reduces ICP, but there is also relatively high RSF due to their size [92].

Considering the diversity of feed solutions, it may not be possible that a single universal DS can treat all kinds of feed solutions [93]. Hence, before applying practically to the real-world industries, a draw solute should be extensively evaluated regarding their suitability through examining its various aspects and the priority order of assessment measure is entirely based on each application. For example, the primary property of a draw solute for power generation via PRO should be water induction ability (high osmotic pressure) since the relationship between power density and water flux is direct proportional [89].

As demonstrated in Figure 3, DS is widely classified into two groups which are synthetic compounds and commercially available compounds that can be further categorized into four main kinds in accordance with their physicochemical properties: volatile compounds, nutrient compounds, inorganic salts, and organic salts but overlapping may occur as this grouping is not strict [94]. 
Commercially available draw solutes were dominant before 2007 and there have been efforts in exploring them but the outcomes are still far from satisfactory, therefore various synthetic DSs that exhibit superiority with lower RSF and less energy consumption in recycling have been proposed recently [95].

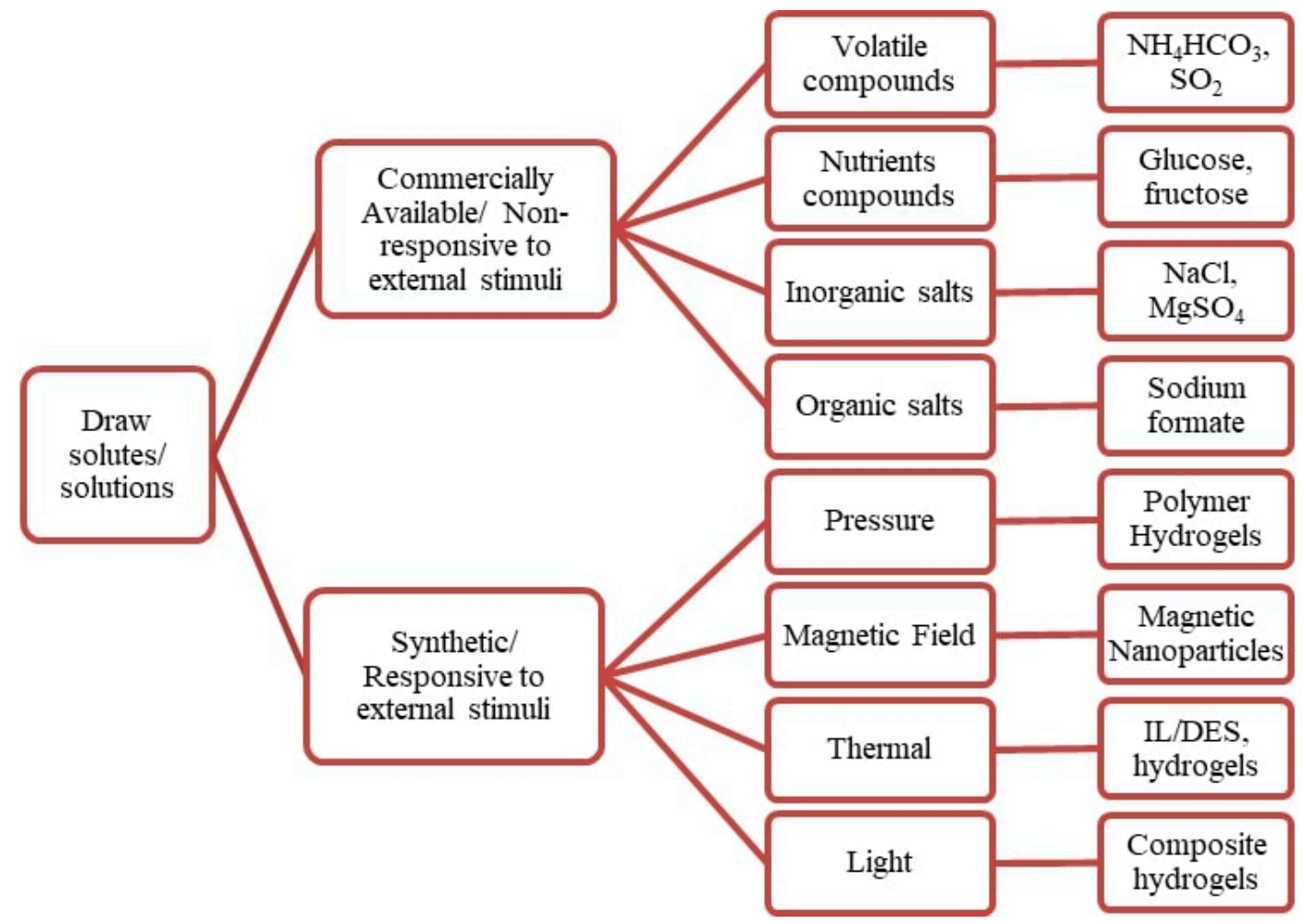

Figure 3. Classification of draw solutes/solution.

There is another classification of DSs based on the recovery methods of draw solute which are either responsive or non-responsive to some external stimuli [93]. The non-responsive draw solutes which include the commercially available compounds refer to those without significant variation in their water affinity upon exposure to stimuli like a magnetic field, thermal, pressure, or light whereas the responsive draw solutes are mostly the synthetic compounds which respond to stimuli by undergoing substantial changes in water affinity. Phase transitions between two states with different water affinities usually happen. Draw solutes can then be easily regenerated or separated from the diluted draw solutions while maintaining drawing ability which is sufficiently high [90].

When the concentration of DS increases, the osmotic pressure difference also increases, resulting in greater water flux. However, this is temporary because there is an enhanced dilutive ICP inside the membrane support layer caused by the increased incoming water flux, reducing the available driving force drastically $[18,96]$. In addition, increased concentration of DS results in a greater draw solutes loss because of RSF, despite being less significant in comparison to the increased Jw. It is noteworthy that if DS concentration is further increased beyond a certain level, the pumping energy will be increased due to the increased viscosity. The use of highly concentrated DS could also result in other implications; for example, chemical exposure to increased ionic concentrations could affect membrane stability [18]. Hence, it is essentially important to develop draw solutes which can produce high water flux at low concentration as this could lead to momentous energy and cost savings.

\section{Operating Conditions}

Furthermore, operating conditions are another factor that highly affects the treatment efficiency of FO. Examples of operating conditions are draw solution concentration, membrane orientation, 
cross-flow velocity and temperature, which are shown in Figure 4. This is also applicable to PRO where the extractable power per unit membrane area (i.e., the specific power) is affected by local conditions such as concentration and temperature of seawater [97]. Moreover, the combined effects of operating conditions should be investigated extensively and the relationship between each variable should be understood so that the performance of ODMPs can be maximized. For example, Hawari, et al. [98] reported a $93.3 \%$ increase in the membrane flux when both the DS temperature and the flow rate are increased from 20 to $26^{\circ} \mathrm{C}$ and from 1.2 to $3.2 \mathrm{~L} / \mathrm{min}$, respectively.

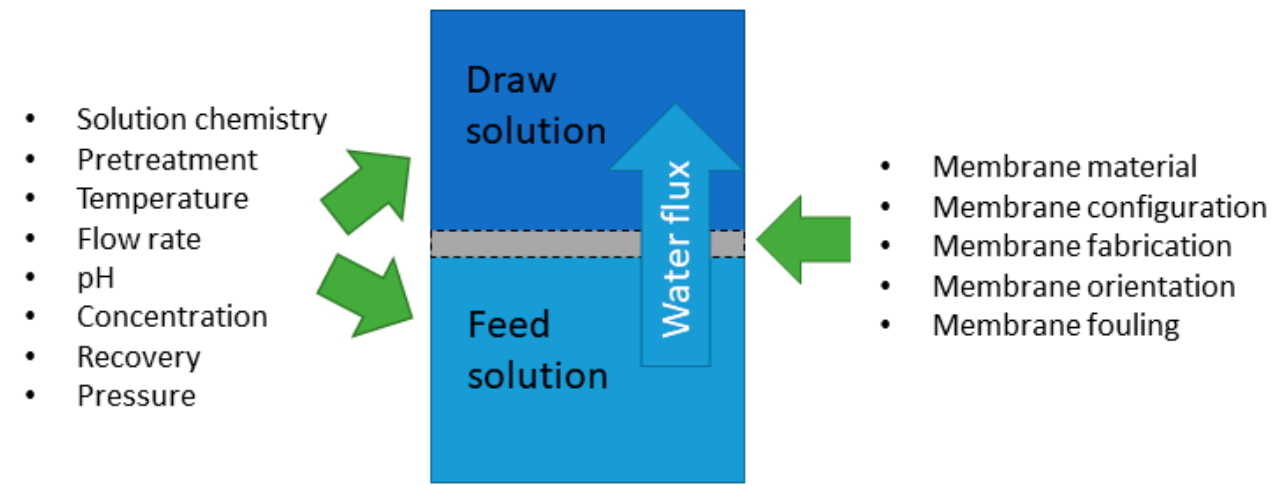

Figure 4. Factors affecting osmotic membrane processes.

Nonetheless, it is a challenge to define a general set of best-operating parameters since they are highly dependent on a particular system where each system has its own membrane parameters, equipment specifications, element geometry, site conditions, and system losses [99]. Maximum power point tracking (MPPT) has been proposed recently to have real-time control of PRO systems by either controlling of only one parameter which is the pressure exerted [100-102] or simultaneously controlling of few parameters including feed flow rates, draw flow rates and pressure exerted [103]. Maximum net power and maximum specific energy can then be extracted from the PRO system at both the design stage and in the field with varying conditions [103]. Nevertheless, laboratory-scale studies are still in great need even though numerous simulation and model-based optimization studies [104-106] have been carried out.

\subsection{Cross-Flow Rate}

According to film theory, the thickness of the mass transfer boundary layer at the membrane surface is changed by varying the flowrate of solutions [107]. When the flow rates are higher, there is an increase in permeate flux because the boundary layer is thinner, resulting in a higher rate of mass transfer, thus reducing ECP and fouling; however, in some cases, it was found that at higher flow rates, the residence time along the membrane will be shorter which will result in lower permeation across the membrane $[23,108]$. Increasing cross-flow velocity induces mixing in the porous support layer making the ICP less severe, especially for those membranes with thin and highly porous support layers [109]. In a cross-flow system, two main forces are applied to the feed particles. Hydrodynamic drag which is perpendicular to the surface of the membrane forces the foulant molecules to move towards the membrane while the shear rate which is tangential to the surface of the membrane causes the molecules to move back towards the bulk solution. Higher tangential shear force at high cross-flow velocities reduces the accumulation of foulants [110]. The removal rate of foulant is also higher [64]. Furthermore, the power density can be influenced by changing the flow rate ratio due to the higher water fluxes obtained from the membrane with a higher flow rate ratio. By understanding the influence of the input flow rate ratio, the potential power output from a PRO system can be increased [111].

A relatively low DS flowrate compared to the FS flowrate will cause dilution effect affecting the permeate flux, which is also more serious with a higher concentration of DS. There should be a 
sufficiently high cross-flow rate of the DS (dilution factor $<2$ ) to restrict the adverse dilution effect [96]. In fact, by altering the flow rates of both the FS and the DS could achieve a greater increment in water flux compared to altering the flow rate of either one. An increase in both flow rates causes a simultaneous reduction of CP effect at both sides of the membrane [98]. It shall be noted that high ratios of flow rate can induce great force to the membrane surface which has the potential to damage the membrane [111]. Hence, research works should be conducted to determine the optimal ratio of flow rates to be implemented.

The study conducted by Phuntsho, Sahebi, Majeed, Lotfi, Kim and Shon [18] has shown higher FO water flux at higher crossflow rates with optimum crossflow rate between 400 and $800 \mathrm{~mL} / \mathrm{min}$, although the increase is logarithmic and the effect of crossflow is insignificant beyond this level. Seker, et al. [112] supported this wherein their study, there was no variation in water flux while increasing flow rate from $2500-7500 \mathrm{~mL} / \mathrm{min}$ as the flow rates used were higher than the optimum. There was a reduction in water fluxes when the flow rate was further increased to $10,000 \mathrm{~mL} / \mathrm{min}$. Also, Gulied, et al. [113] found out that a small increase in water flux $(\sim 1.5 \%)$ and $\% \mathrm{~W}$ recovery $(1.2 \%)$ were resulted from increasing the flow rate from $1600-2800 \mathrm{~mL} / \mathrm{min}$. However, when the circulation flow rate increased, the ECP effect could become smaller reducing the water flux where the WF and \%W recovery decreased gradually with increasing flow rates from $2800-3200 \mathrm{~mL} / \mathrm{min}$.

In addition, there is a requirement of extra pumping energy for high cross-flow rates yet the enhancement on water flux may be limited. For instance, the study reported by Gulied, Al Momani, Khraisheh, Bhosale and AlNouss [113] observed there was no significant effect on FO performance by increasing circulation flow rate (from $1.6 \mathrm{~mL} / \mathrm{min}$ to $3.2 \mathrm{~mL} / \mathrm{min}$ ) but energy consumption increased from $36.1 \mathrm{~W} / \mathrm{m}^{3}$ to $144.2 \mathrm{~W} / \mathrm{m}^{3}$. This indicates that energy consumption increased by $\sim 4$-fold when doubling the flow rates. The efficiency of the PRO process is reduced as a result of increased energy need for pumping even though increasing cross-flow rates leads to increased power densities [114]. In certain cases and up to certain limits, improvement in osmotic performance and power generation can justify the energy invested for additional pumping [103]. At the optimal cross-flow, a balance of pumping energy and osmotic performance shall be accomplished [96].

\subsection{Temperature}

Operating temperature is a crucial factor which affects the osmotic performance. This is because it has a direct influence on the thermodynamic properties of both solutions, (e.g., osmotic pressure, diffusion, and viscosity) [115]. In fact, according to the van 't Hoff equation ( $\pi=\beta C R T)$, there is a direct proportional relationship between osmotic pressure and the temperature. Although the osmotic pressure is not proportional to the concentration if the solutions are highly concentrated, there is still an assumption of the proportionality between the osmotic pressure and the temperature [116]. Variation in the thermodynamic properties not only affects the water flux but also influences membrane fouling and solute rejection/diffusion [117]. Heating both sides (FS and DS) simultaneously is more effective since the difference among the water fluxes with increased temperature of either one solution is not significant [115].

An increase in the temperature improves the water flux due to reduced water viscosity in solutions (and/or solubility), and increased water solubility and diffusivity within the membrane [117]. Besides variations in properties of solvent, solute, and solution, there is higher water flux because the polymeric membrane expands upon heating producing larger effective pore sizes, which also unfortunately gives rise to more serious solute diffusion [118]. RSF increases with the increase of temperature as the membrane has less resistance to draw solute transmembrane diffusion [115]. Although the increased solute diffusion alleviates the concentrative ICP in the support layer and increases the water flux, dilutive ECP can be enhanced because such an improved water flux carries more solutes from the feed bulk phase to the surface of the support layer, thereby reducing the available driving force [117].

Furthermore, an increase in water flux leads to a reduction of operation time; for example, Yang, Gao, Jang, Shon and Yue [83] demonstrated reducing sewage to one-quarter volume using FO filtration 
took $46 \mathrm{~h}$ and $15 \mathrm{~h}$ at $15{ }^{\circ} \mathrm{C}$ and $35^{\circ} \mathrm{C}$, respectively. In addition to increasing water flux, higher temperature generally results in higher power density. Simulated model by Anastasio, et al. [119] predicted that power density is greater at elevated temperature since membrane hydraulic permeance, draw osmotic pressure and solute diffusivity all raise with temperature. Table 5 demonstrates how an increase in temperature affects water flux and/or specific power in previous studies. Most of the studies reported the improvement with increasing temperature, but higher temperatures can be tested for the resulting performance together with their effects on membrane and energy efficiency.

Table 5. Increase in water flux and/or specific power due to increase in temperature.

\begin{tabular}{|c|c|c|c|c|c|c|}
\hline Membrane & FS & DS & $\begin{array}{c}\text { Temperature } \\
\left({ }^{\circ} \mathrm{C}\right)\end{array}$ & $\begin{array}{l}\text { Increase in } \\
\text { Water Flux } \\
\text { Per }{ }^{\circ} \mathrm{C}(\%)\end{array}$ & $\begin{array}{l}\text { Increase in } \\
\text { Specific } \\
\text { Power Per } \\
{ }^{\circ} \mathrm{C}(\%)\end{array}$ & Ref. \\
\hline CTA-HTI & $\begin{array}{l}\text { Brackish } \\
\text { water }\end{array}$ & $\begin{array}{c}1.5 \mathrm{M} \\
\mathrm{Na}_{2} \mathrm{SO}_{4}\end{array}$ & $\begin{array}{l}25-35 \\
35-45\end{array}$ & $\begin{array}{l}3.1 \\
1.2\end{array}$ & - & $\begin{array}{l}\text { Zhao and } \\
\text { Zou [120] }\end{array}$ \\
\hline CTA-HTI & $10 \mathrm{mM} \mathrm{NaCl}$ & $1 \mathrm{M} \mathrm{NaCl}$ & $25-35$ & 4.1 & 3.4 & $\begin{array}{c}\text { She, Jin and } \\
\text { Tang [71] }\end{array}$ \\
\hline CTA-HTI & $\begin{array}{c}\text { Brackish } \\
\text { water }\end{array}$ & $0.5 \mathrm{M} \mathrm{KCl}$ & $\begin{array}{l}25-35 \\
25-45\end{array}$ & $\begin{array}{l}1.7 \\
3.2 \\
\end{array}$ & - & $\begin{array}{l}\text { Phuntsho, et } \\
\text { al. [121] }\end{array}$ \\
\hline CTA-HTI & $0.5 \mathrm{M} \mathrm{NaCl}$ & $\begin{array}{c}1 \mathrm{M} \mathrm{NaCl} \\
1.5 \mathrm{M} \mathrm{NaCl} \\
2 \mathrm{M} \mathrm{NaCl}\end{array}$ & $20-30$ & $\begin{array}{l}7.1 \\
3.9 \\
5.0\end{array}$ & $\begin{array}{l}6.5 \\
3.3 \\
4.7\end{array}$ & $\begin{array}{c}\text { Kim and } \\
\text { Elimelech } \\
\text { [122] }\end{array}$ \\
\hline CA-HTI & DI water & $1.5 \mathrm{M} \mathrm{NaCl}$ & $20-40$ & - & 5.2 & $\begin{array}{c}\text { Anastasio, } \\
\text { Arena, Cole } \\
\text { and } \\
\text { McCutcheon } \\
\text { [119] }\end{array}$ \\
\hline CTA-HTI & DI water & $2 \mathrm{M} \mathrm{NaCl}$ & $\begin{array}{c}5-20 \\
20-45\end{array}$ & $\begin{array}{l}2.9 \\
3.3\end{array}$ & - & $\begin{array}{l}\text { Heo, et al. } \\
\text { [123] }\end{array}$ \\
\hline TFC-TCK & $0.01 \mathrm{M} \mathrm{NaCl}$ & $\begin{array}{l}0.6 \mathrm{M} \mathrm{NaCl} \\
1.2 \mathrm{M} \mathrm{NaCl}\end{array}$ & $25-50$ & $\begin{array}{l}2.9 \\
3.0\end{array}$ & $\begin{array}{l}3.2 \\
3.1\end{array}$ & $\begin{array}{c}\text { Wang, et al. } \\
\text { [124] }\end{array}$ \\
\hline TFC & $\begin{array}{c}\text { Municipal } \\
\text { wastewater }\end{array}$ & $\begin{array}{c}\text { Synthetic } \\
\text { seawater } \\
\text { concentrate }\end{array}$ & $\begin{array}{l}15-25 \\
25-35\end{array}$ & $\begin{array}{l}4.0 \\
1.9\end{array}$ & - & $\begin{array}{c}\text { Yang, Gao, } \\
\text { Jang, Shon } \\
\text { and Yue [83] }\end{array}$ \\
\hline
\end{tabular}

\section{Conclusions}

There is an extensive potential in ODMPs, specifically FO and PRO, to act as a sustainable bioenergy solution on water and energy scarcity. However, technological developments and large-scale investigations are required to improve their feasibility and performance. This review provides a comprehensive summary of factors affecting their performance so that these efficient and green bioenergy processes can be further improved and implemented in the industrial applications in the near future. Membrane FS and DS, which are the major components of ODMPs, have high impacts on the performance of FO and PRO. These components which are commercially available should be modified for better performance. For example, research should be carried out to improve the pressure stability of TFC membranes for higher power density. Efforts must also be carried out on exploring new materials to fabricate membrane as well as to synthesize FS and DS so that higher water flux and greater power density can be achieved, thereby improving the bioenergy production. Draw solution with high salinity should be explored and examined to enhance the power generation to compete with other renewable energies. Also, optimization of operating parameters and understanding of the relationship between these parameters are essential to maximizing the bioenergy output. Although the performance of osmotic membrane processes (i.e., water flux and power density) is not affected by 
their economics, the cost aspect-including membrane cost and pretreatment cost—is an important criterion for consideration when designing an osmotic system, especially for bioenergy applications. Therefore, a techno-economic assessment of these osmotic membrane processes is essential to examine their feasibility even though there is a lack of full-scale FO and PRO applications to validate the cost assumption. In short, this paper has summarized the factors affecting FO and PRO processes which help in bioenergy production while outlining research needs and future directions on each factor.

Author Contributions: Writing-original draft, W.Y.C.; Writing-review \& editing, K.S.K. and S.R.C.; Conceptualization, K.W.C. and G.Y.Y.; Supervision \& Funding acquisition, Y.-C.H., P.L.S. and W.-H.C. All authors have read and agreed to the published version of the manuscript.

Funding: This work was supported by the Fundamental Research Grant Scheme, Malaysia (FRGS/1/2019/STG05/ UNIM/02/2) and funded by PETRONAS under the YUTP grant (015LC0-169). The authors acknowledge the financial support of the Ministry of Science and Technology, Taiwan, R.O.C., under the contracts MOST 106-2923-E-006-002-MY3 and MOST 108-3116-F-006-007-CC1 for this research. This research was also supported in part by Higher Education Sprout Project, Ministry of Education to the Headquarters of University Advancement at NCKU.

Conflicts of Interest: The authors declare no conflict of interest.

\section{References}

1. Chung, T.-S.; Luo, L.; Wan, C.F.; Cui, Y.; Amy, G. What is next for forward osmosis (FO) and pressure retarded osmosis (PRO). Sep. Purif. Technol. 2015, 156, 856-860. [CrossRef]

2. Zhang, B.; Gao, H.; Tong, X.; Liu, S.; Gan, L.; Chen, Y. Chapter 6-Pressure Retarded Osmosis and Reverse Electrodialysis as Power Generation Membrane Systems. In Current Trends and Future Developments on (Bio-) Membranes; Basile, A., Cassano, A., Figoli, A., Eds.; Elsevier: Amsterdam, The Netherlands, 2019; pp. 133-152.

3. Zhao, S.; Zou, L.; Tang, C.Y.; Mulcahy, D. Recent developments in forward osmosis: Opportunities and challenges. J. Membr. Sci. 2012, 396, 1-21. [CrossRef]

4. Cath, T.Y.; Childress, A.E.; Elimelech, M. Forward osmosis: Principles, applications, and recent developments. J. Membr. Sci. 2006, 281, 70-87. [CrossRef]

5. Helfer, F.; Lemckert, C.; Anissimov, Y.G. Osmotic power with Pressure Retarded Osmosis: Theory, performance and trends-A review. J. Membr. Sci. 2014, 453, 337-358. [CrossRef]

6. Sarp, S. Chapter 11-Fundamentals of Pressure Retarded Osmosis. In Current Trends and Future Developments on (Bio-) Membranes; Basile, A., Curcio, E., Inamuddin, Eds.; Elsevier: Amsterdam, The Netherlands, 2019; pp. 271-283.

7. Sarp, S.; Li, Z.; Saththasivam, J. Pressure Retarded Osmosis (PRO): Past experiences, current developments, and future prospects. Desalination 2016, 389, 2-14. [CrossRef]

8. Yang, E.; Kim, K.-Y.; Chae, K.-J.; Lee, M.-Y.; Kim, I.S. Evaluation of energy and water recovery in forward osmosis-bioelectrochemical hybrid system with cellulose triacetate and polyamide asymmetric membrane in different orientations. Desalin. Water. Treat. 2016, 57, 7406-7413. [CrossRef]

9. Zhang, F.; Brastad, K.S.; He, Z. Integrating Forward Osmosis into Microbial Fuel Cells for Wastewater Treatment, Water Extraction and Bioelectricity Generation. Environ. Sci. Technol. 2011, 45, 6690-6696. [CrossRef] [PubMed]

10. Chia, S.R.; Chew, K.W.; Show, P.L.; Yap, Y.J.; Ong, H.C.; Ling, T.C.; Chang, J.-S. Analysis of Economic and Environmental Aspects of Microalgae Biorefinery for Biofuels Production: A Review. Biotechnol. J. 2018, 13, 1700618. [CrossRef] [PubMed]

11. Phwan, C.K.; Chew, K.W.; Sebayang, A.H.; Ong, H.C.; Ling, T.C.; Malek, M.A.; Ho, Y.-C.; Show, P.L. Effects of acids pre-treatment on the microbial fermentation process for bioethanol production from microalgae. Biotechnol. Biofuels 2019, 12, 191. [CrossRef]

12. Alsvik, L.I.; Hägg, M.-B. Pressure Retarded Osmosis and Forward Osmosis Membranes: Materials and Methods. Polymers 2013, 5, 303-327. [CrossRef]

13. She, Q.; Wang, R.; Fane, A.G.; Tang, C.Y. Membrane fouling in osmotically driven membrane processes: A review. J. Membr. Sci. 2016, 499, 201-233. [CrossRef]

14. Han, G.; Zhang, S.; Li, X.; Chung, T.-S. Progress in pressure retarded osmosis (PRO) membranes for osmotic power generation. Prog. Polym. Sci. 2015, 51,1-27. [CrossRef] 
15. Goh, P.S.; Ismail, A.F.; Ng, B.C.; Abdullah, M.S. Recent Progresses of Forward Osmosis Membranes Formulation and Design for Wastewater Treatment. Water 2019, 11, 2043. [CrossRef]

16. Yip, N.Y.; Tiraferri, A.; Phillip, W.A.; Schiffman, J.D.; Elimelech, M. High performance thin-film composite forward osmosis membrane. Environ. Sci. Technol. 2010, 44, 3812-3818. [CrossRef]

17. McCutcheon, J.R.; Elimelech, M. Influence of concentrative and dilutive internal concentration polarization on flux behavior in forward osmosis. J. Membr. Sci. 2006, 284, 237-247. [CrossRef]

18. Phuntsho, S.; Sahebi, S.; Majeed, T.; Lotfi, F.; Kim, J.E.; Shon, H.K. Assessing the major factors affecting the performances of forward osmosis and its implications on the desalination process. Chem. Eng. J. 2013, 231, 484-496. [CrossRef]

19. McCutcheon, J.R.; Elimelech, M. Influence of membrane support layer hydrophobicity on water flux in osmotically driven membrane processes. J. Membr. Sci. 2008, 318, 458-466. [CrossRef]

20. Population Distribution and Water Scarcity. Recent Developments in Forward Osmosis Processes; Linares, R.V., Li, Z., Elimelech, M., Amy, G., Vrouwenvelder, H., Eds.; IWA Publishing: London, UK, 2017.

21. Klaysom, C.; Cath, T.Y.; Depuydt, T.; Vankelecom, I.F. Forward and pressure retarded osmosis: Potential solutions for global challenges in energy and water supply. Chem. Soc. Rev. 2013, 42, 6959-6989. [CrossRef]

22. Majeed, T.; Lotfi, F.; Phuntsho, S.; Yoon, J.K.; Kim, K.; Shon, H.K. Performances of PA hollow fiber membrane with the CTA flat sheet membrane for forward osmosis process. Desalin. Water Treat. 2015, 53, 1744-1754. [CrossRef]

23. Wong, M.C.Y.; Martinez, K.; Ramon, G.Z.; Hoek, E.M.V. Impacts of operating conditions and solution chemistry on osmotic membrane structure and performance. Desalination 2012, 287, 340-349. [CrossRef]

24. Lee, K.L.; Baker, R.W.; Lonsdale, H.K. Membranes for power generation by pressure-retarded osmosis. J. Membr. Sci. 1981, 8, 141-171. [CrossRef]

25. Sarp, S.; Hilal, N. Chapter 8-Membrane Modules for Large-Scale Salinity Gradient Process Applications. In Membrane-Based Salinity Gradient Processes for Water Treatment and Power Generation; Sarp, S., Hilal, N., Eds.; Elsevier: Amsterdam, The Netherlands, 2018; pp. 223-242.

26. Li, X.; Zhang, S.; Fu, F.; Chung, T.-S. Deformation and reinforcement of thin-film composite (TFC) polyamide-imide (PAI) membranes for osmotic power generation. J. Membr. Sci. 2013, 434, $204-217$. [CrossRef]

27. Qasim, M.; Darwish, N.A.; Sarp, S.; Hilal, N. Water desalination by forward (direct) osmosis phenomenon: A comprehensive review. Desalination 2015, 374, 47-69. [CrossRef]

28. Wei, J.; Qiu, C.; Tang, C.Y.; Wang, R.; Fane, A.G. Synthesis and characterization of flat-sheet thin film composite forward osmosis membranes. J. Membr. Sci. 2011, 372, 292-302. [CrossRef]

29. Lim, S.W.; Mah, S.-K.; Lee, Z.H.; Chai, S.-P. A study of water permeation using glycerol as the draw solution with thin film composite membranes in forward osmosis and pressure retarded osmosis configurations. AIP Conf. Proc. 2018, 2031, 020020.

30. Wang, Z.; Tang, J.; Zhu, C.; Dong, Y.; Wang, Q.; Wu, Z. Chemical cleaning protocols for thin film composite (TFC) polyamide forward osmosis membranes used for municipal wastewater treatment. J. Membr. Sci. 2015, 475, 184-192. [CrossRef]

31. Fam, W.; Phuntsho, S.; Lee, J.H.; Shon, H.K. Performance comparison of thin-film composite forward osmosis membranes. Desalin. Water Treat. 2013, 51, 6274-6280. [CrossRef]

32. Li, J.-Y.; Ni, Z.-Y.; Zhou, Z.-Y.; Hu, Y.-X.; Xu, X.-H.; Cheng, L.-H. Membrane fouling of forward osmosis in dewatering of soluble algal products: Comparison of TFC and CTA membranes. J. Membr. Sci. 2018, 552, 213-221. [CrossRef]

33. Madsen, H.T.; Nissen, S.S.; Muff, J.; Søgaard, E.G. Pressure retarded osmosis from hypersaline solutions: Investigating commercial FO membranes at high pressures. Desalination 2017, 420, 183-190. [CrossRef]

34. Wan, C.F.; Cui, Y.; Gai, W.X.; Cheng, Z.L.; Chung, T.-S. Chapter 14-Nanostructured Membranes for Enhanced Forward Osmosis and Pressure-Retarded Osmosis. In Sustainable Nanoscale Engineering; Szekely, G., Livingston, A., Eds.; Elsevier: Amsterdam, The Netherlands, 2020; pp. 373-394.

35. Sakai, M.; Seshimo, M.; Matsukata, M. Hydrophilic ZSM-5 membrane for forward osmosis operation. J. Water Process Eng. 2019, 32, 100864. [CrossRef]

36. Chung, T.-S.; Zhao, D.; Gao, J.; Lu, K.; Wan, C.; Weber, M.; Maletzko, C. Emerging R\&D on membranes and systems for water reuse and desalination. Chin. J. Chem. Eng. 2019, 27, 1578-1585. 
37. Sahebi, S.; Sheikhi, M.; Ramavandi, B. A new biomimetic aquaporin thin film composite membrane for forward osmosis: Characterization and performance assessment. Desalin. Water Treat. 2019, 148, 42-50. [CrossRef]

38. Li, Y.; Zhao, Y.; Tian, E.; Ren, Y. Preparation and characterization of novel forward osmosis membrane incorporated with sulfonated carbon nanotubes. RSC Adv. 2018, 8, 41032-41039. [CrossRef]

39. Salehi, T.M.; Peyravi, M.; Jahanshahi, M.; Lau, W.-J.; Rad, A.S. Impacts of zeolite nanoparticles on substrate properties of thin film nanocomposite membranes for engineered osmosis. J. Nanoparticle Res. 2018, 20, 113. [CrossRef]

40. Lee, W.J.; Goh, P.S.; Lau, W.J.; Ong, C.S.; Ismail, A.F. Antifouling zwitterion embedded forward osmosis thin film composite membrane for highly concentrated oily wastewater treatment. Sep. Purif. Technol. 2019, 214, 40-50. [CrossRef]

41. Shokrgozar Eslah, S.; Shokrollahzadeh, S.; Moini Jazani, O.; Samimi, A. Forward osmosis water desalination: Fabrication of graphene oxide-polyamide/polysulfone thin-film nanocomposite membrane with high water flux and low reverse salt diffusion. Sep. Sci. Technol. 2018, 53, 573-583. [CrossRef]

42. Gai, W.; Zhao, D.L.; Chung, T.-S. Thin film nanocomposite hollow fiber membranes comprising $\mathrm{Na}$-functionalized carbon quantum dots for brackish water desalination. Water Res. 2019, 154, 54-61. [CrossRef]

43. Amini, M.; Shekari, Z.; Hosseinifard, M.; Seidi, F. Preparation and Characterization of Thin-Film Nanocomposite Membrane Incorporated with MoO3 Nanoparticles with High Flux Performance for Forward Osmosis. ChemistrySelect 2019, 4, 7832-7837. [CrossRef]

44. Gonzales, R.R.; Park, M.J.; Tijing, L.; Han, D.S.; Phuntsho, S.; Shon, H.K. Modification of Nanofiber Support Layer for Thin Film Composite Forward Osmosis Membranes via Layer-by-Layer Polyelectrolyte Deposition. Membranes 2018, 8, 70. [CrossRef]

45. Dai, R.; Zhang, X.; Liu, M.; Wu, Z.; Wang, Z. Porous metal organic framework CuBDC nanosheet incorporated thin-film nanocomposite membrane for high-performance forward osmosis. J. Membr. Sci. 2019, 573, 46-54. [CrossRef]

46. Subramani, A.; Jacangelo, J.G. Emerging desalination technologies for water treatment: A critical review. Water Res. 2015, 75, 164-187. [CrossRef] [PubMed]

47. Chou, S.; Wang, R.; Fane, A.G. Robust and High performance hollow fiber membranes for energy harvesting from salinity gradients by pressure retarded osmosis. J. Membr. Sci. 2013, 448, 44-54. [CrossRef]

48. Goh, P.S.; Ismail, A.F. Chapter 5-Flat-Sheet Membrane for Power Generation and Desalination Based on Salinity Gradient. In Membrane-Based Salinity Gradient Processes for Water Treatment and Power Generation; Sarp, S., Hilal, N., Eds.; Elsevier: Amsterdam, The Netherlands, 2018; pp. 155-174.

49. Wang, Y.-N.; Goh, K.; Li, X.; Setiawan, L.; Wang, R. Membranes and processes for forward osmosis-based desalination: Recent advances and future prospects. Desalination 2018, 434, 81-99. [CrossRef]

50. Crowder, M.L.; Gooding, C.H. Spiral wound, hollow fiber membrane modules: A new approach to higher mass transfer efficiency. J. Membr. Sci. 1997, 137, 17-29. [CrossRef]

51. Wang, R.; Shi, L.; Tang, C.Y.; Chou, S.; Qiu, C.; Fane, A.G. Characterization of novel forward osmosis hollow fiber membranes. J. Membr. Sci. 2010, 355, 158-167. [CrossRef]

52. Bajraktari, N.; Hélix-Nielsen, C.; Madsen, H.T. Pressure retarded osmosis from hypersaline sources-A review. Desalination 2017, 413, 65-85. [CrossRef]

53. Lau, W.-J.; Lai, G.-S.; Li, J.; Gray, S.; Hu, Y.; Misdan, N.; Goh, P.-S.; Matsuura, T.; Azelee, I.W.; Ismail, A.F. Development of microporous substrates of polyamide thin film composite membranes for pressure-driven and osmotically-driven membrane processes: A review. J. Ind. Eng. Chem. 2019, 77, 25-59. [CrossRef]

54. Saito, K.; Irie, M.; Zaitsu, S.; Sakai, H.; Hayashi, H.; Tanioka, A. Power generation with salinity gradient by pressure retarded osmosis using concentrated brine from SWRO system and treated sewage as pure water. Desalin. Water Treat. 2012, 41, 114-121. [CrossRef]

55. Sharma, M.; Mondal, P.; Chakraborty, A.; Kuttippurath, J.; Purkait, M. Effect of different molecular weight polyethylene glycol on flat sheet cellulose acetate membranes for evaluating power density performance in pressure retarded osmosis study. J. Water Process Eng. 2019, 30, 100632. [CrossRef]

56. Wan, C.F.; Yang, T.; Gai, W.; Lee, Y.D.; Chung, T.-S. Thin-film composite hollow fiber membrane with inorganic salt additives for high mechanical strength and high power density for pressure-retarded osmosis. J. Membr. Sci. 2018, 555, 388-397. [CrossRef] 
57. Park, M.J.; Lim, S.; Gonzales, R.R.; Phuntsho, S.; Han, D.S.; Abdel-Wahab, A.; Adham, S.; Shon, H.K. Thin-film composite hollow fiber membranes incorporated with graphene oxide in polyethersulfone support layers for enhanced osmotic power density. Desalination 2019, 464, 63-75. [CrossRef]

58. Zhang, Y.; Li, J.L.; Cai, T.; Cheng, Z.L.; Li, X.; Chung, T.-S. Sulfonated hyperbranched polyglycerol grafted membranes with antifouling properties for sustainable osmotic power generation using municipal wastewater. J. Membr. Sci. 2018, 563, 521-530. [CrossRef]

59. Gonzales, R.R.; Park, M.J.; Bae, T.-H.; Yang, Y.; Abdel-Wahab, A.; Phuntsho, S.; Shon, H.K. Melamine-based covalent organic framework-incorporated thin film nanocomposite membrane for enhanced osmotic power generation. Desalination 2019, 459, 10-19. [CrossRef]

60. Lim, S.; Park, M.J.; Phuntsho, S.; Mai-Prochnow, A.; Murphy, A.B.; Seo, D.; Shon, H. Dual-layered nanocomposite membrane incorporating graphene oxide and halloysite nanotube for high osmotic power density and fouling resistance. J. Membr. Sci. 2018, 564, 382-393. [CrossRef]

61. Wan, C.F.; Li, B.; Yang, T.; Chung, T.-S. Design and fabrication of inner-selective thin-film composite (TFC) hollow fiber modules for pressure retarded osmosis (PRO). Sep. Purif. Technol. 2017, 172, 32-42. [CrossRef]

62. Wan, C.F.; Chung, T.-S. Osmotic power generation by pressure retarded osmosis using seawater brine as the draw solution and wastewater retentate as the feed. J. Membr. Sci. 2015, 479, 148-158. [CrossRef]

63. Rana, D.; Matsuura, T. Surface Modifications for Antifouling Membranes. Chem. Rev. 2010, 110, $2448-2471$. [CrossRef]

64. Nagy, E.; Hegedüs, I.; Tow, E.W.; Lienhard, V.J.H. Effect of fouling on performance of pressure retarded osmosis (PRO) and forward osmosis (FO). J. Membr. Sci. 2018, 565, 450-462. [CrossRef]

65. Le, N.L.; Nunes, S.P. Materials and membrane technologies for water and energy sustainability. Sustain. Mater. Technol. 2016, 7, 1-28. [CrossRef]

66. Ibrar, I.; Naji, O.; Sharif, A.; Malekizadeh, A.; Alhawari, A.; Alanezi, A.A.; Altaee, A. A Review of Fouling Mechanisms, Control Strategies and Real-Time Fouling Monitoring Techniques in Forward Osmosis. Water 2019, 11, 695. [CrossRef]

67. Mi, B.; Elimelech, M. Chemical and physical aspects of organic fouling of forward osmosis membranes. J. Membr. Sci. 2008, 320, 292-302. [CrossRef]

68. Zhao, P.; Gao, B.; Yue, Q.; Liu, P.; Shon, H.K. Fatty acid fouling of forward osmosis membrane: Effects of $\mathrm{pH}$, calcium, membrane orientation, initial permeate flux and foulant composition. J. Environ. Sci. 2016, 46, 55-62. [CrossRef] [PubMed]

69. Abbasi-Garravand, E.; Mulligan, C.N.; Laflamme, C.B.; Clairet, G. Investigation of the fouling effect on a commercial semi-permeable membrane in the pressure retarded osmosis (PRO) process. Sep. Purif. Technol. 2018, 193, 81-90. [CrossRef]

70. Zhao, S.; Zou, L.; Mulcahy, D. Effects of membrane orientation on process performance in forward osmosis applications. J. Membr. Sci. 2011, 382, 308-315. [CrossRef]

71. She, Q.; Jin, X.; Tang, C.Y. Osmotic power production from salinity gradient resource by pressure retarded osmosis: Effects of operating conditions and reverse solute diffusion. J. Membr. Sci. 2012, 401-402, 262-273. [CrossRef]

72. Yip, N.Y.; Elimelech, M. Influence of natural organic matter fouling and osmotic backwash on pressure retarded osmosis energy production from natural salinity gradients. Environ. Sci. Technol. 2013, 47, 12607-12616. [CrossRef]

73. Chun, Y.; Mulcahy, D.; Zou, L.; Kim, I.S. A Short Review of Membrane Fouling in Forward Osmosis Processes. Membranes 2017, 7, 30. [CrossRef]

74. Jiang, S.; Li, Y.; Ladewig, B.P. A review of reverse osmosis membrane fouling and control strategies. Sci. Total Environ. 2017, 595, 567-583. [CrossRef]

75. Singh, N.; Dhiman, S.; Basu, S.; Balakrishnan, M.; Petrinic, I.; Helix-Nielsen, C. Dewatering of sewage for nutrients and water recovery by Forward Osmosis (FO) using divalent draw solution. J. Water Process Eng. 2019, 31, 100853. [CrossRef]

76. Xue, W.; Tobino, T.; Nakajima, F.; Yamamoto, K. Seawater-driven forward osmosis for enriching nitrogen and phosphorous in treated municipal wastewater: Effect of membrane properties and feed solution chemistry. Water Res. 2015, 69, 120-130. [CrossRef] 
77. Wang, J.; Xiao, T.; Bao, R.; Li, T.; Wang, Y.; Li, D.; Li, X.; He, T. Zwitterionic surface modification of forward osmosis membranes using $\mathrm{N}$-aminoethyl piperazine propane sulfonate for grey water treatment. Process Saf. Environ. Prot. 2018, 116, 632-639. [CrossRef]

78. Son, J.; Sung, M.; Ryu, H.; Oh, Y.-K.; Han, J.-I. Microalgae dewatering based on forward osmosis employing proton exchange membrane. Bioresour. Technol. 2017, 244, 57-62. [CrossRef]

79. Yun, T.; Kim, Y.-J.; Lee, S.; Hong, S.; Kim, G.I. Flux behavior and membrane fouling in pressure-assisted forward osmosis. Desalin. Water Treat. 2014, 52, 564-569. [CrossRef]

80. Nave, F.; Kommalapati, R.; Thompson, A. Introductory Chapter: Osmotically Driven Membrane Processes. In Osmotically Driven Membrane Processes-Approach, Development and Current Status; IntechOpen: London, UK, 2018.

81. Yang, T.; Wan, C.F.; Xiong, J.Y.; Chung, T.-S. Pre-treatment of wastewater retentate to mitigate fouling on the pressure retarded osmosis (PRO) process. Sep. Purif. Technol. 2019, 215, 390-397. [CrossRef]

82. Choi, Y.; Vigneswaran, S.; Lee, S. Evaluation of fouling potential and power density in pressure retarded osmosis (PRO) by fouling index. Desalination 2016, 389, 215-223. [CrossRef]

83. Yang, S.; Gao, B.; Jang, A.; Shon, H.K.; Yue, Q. Municipal wastewater treatment by forward osmosis using seawater concentrate as draw solution. Chemosphere 2019, 237, 124485. [CrossRef] [PubMed]

84. Chen, Y.; Liu, C.; Setiawan, L.; Wang, Y.-N.; Hu, X.; Wang, R. Enhancing pressure retarded osmosis performance with low-pressure nanofiltration pretreatment: Membrane fouling analysis and mitigation. J. Membr. Sci. 2017, 543, 114-122. [CrossRef]

85. Wan, C.F.; Jin, S.; Chung, T.-S. Mitigation of inorganic fouling on pressure retarded osmosis (PRO) membranes by coagulation pretreatment of the wastewater concentrate feed. J. Membr. Sci. 2019, 572, 658-667. [CrossRef]

86. Seker, M.; Buyuksari, E.; Topcu, S.; Babaoglu, D.S.; Celebi, D.; Keskinler, B.; Aydiner, C. Effect of pretreatment and membrane orientation on fluxes for concentration of whey with high foulants by using NH3/CO2 in forward osmosis. Bioresour. Technol. 2017, 243, 237-246. [CrossRef]

87. Kim, M.; Kim, S. Practical limit of energy production from seawater by full-scale pressure retarded osmosis. Energy 2018, 158, 373-382. [CrossRef]

88. Chekli, L.; Phuntsho, S.; Shon, H.K.; Vigneswaran, S.; Kandasamy, J.; Chanan, A. A review of draw solutes in forward osmosis process and their use in modern applications. Desalin. Water Treat. 2012, 43, 167-184. [CrossRef]

89. Gwak, G.; Hong, S. Chapter 3-Draw Solute Selection. In Membrane-Based Salinity Gradient Processes for Water Treatment and Power Generation; Sarp, S., Hilal, N., Eds.; Elsevier: Amsterdam, The Netherlands, 2018; pp. 87-122.

90. Cai, Y.; Hu, X.M. A critical review on draw solutes development for forward osmosis. Desalination 2016, 391, 16-29. [CrossRef]

91. Alejo, T.; Arruebo, M.; Carcelen, V.; Monsalvo, V.M.; Sebastian, V. Advances in draw solutes for forward osmosis: Hybrid organic-inorganic nanoparticles and conventional solutes. Chem. Eng. J. 2017, 309, 738-752. [CrossRef]

92. Johnson, D.J.; Suwaileh, W.A.; Mohammed, A.W.; Hilal, N. Osmotic's potential: An overview of draw solutes for forward osmosis. Desalination 2018, 434, 100-120. [CrossRef]

93. Dutta, S.; Nath, K. Prospect of ionic liquids and deep eutectic solvents as new generation draw solution in forward osmosis process. J. Water Process Eng. 2018, 21, 163-176. [CrossRef]

94. Ge, Q.; Ling, M.; Chung, T.-S. Draw solutions for forward osmosis processes: Developments, challenges, and prospects for the future. J. Membr. Sci. 2013, 442, 225-237. [CrossRef]

95. Chen, Q.; Xu, W.; Ge, Q. Synthetic draw solutes for forward osmosis: Status and future. Rev. Chem. Eng. 2018, 34, 767. [CrossRef]

96. Xu, Y.; Peng, X.; Tang, C.Y.; Fu, Q.S.; Nie, S. Effect of draw solution concentration and operating conditions on forward osmosis and pressure retarded osmosis performance in a spiral wound module. J. Membr. Sci. 2010, 348, 298-309. [CrossRef]

97. Sivertsen, E.; Holt, T.; Thelin, W.R. Concentration and Temperature Effects on Water and Salt Permeabilities in Osmosis and Implications in Pressure-Retarded Osmosis. Membranes 2018, 8, 39. [CrossRef]

98. Hawari, A.H.; Kamal, N.; Altaee, A. Combined influence of temperature and flow rate of feeds on the performance of forward osmosis. Desalination 2016, 398, 98-105. [CrossRef] 
99. Maisonneuve, J.; Pillay, P.; Laflamme, C.B. Pressure-retarded osmotic power system model considering non-ideal effects. Renew. Energy 2015, 75, 416-424. [CrossRef]

100. He, W.; Luo, X.; Kiselychnyk, O.; Wang, J.; Shaheed, M.H. Maximum power point tracking (MPPT) control of pressure retarded osmosis (PRO) salinity power plant: Development and comparison of different techniques. Desalination 2016, 389, 187-196. [CrossRef]

101. He, W.; Wang, Y.; Shaheed, M.H. Maximum power point tracking (MPPT) of a scale-up pressure retarded osmosis (PRO) osmotic power plant. Appl. Energy 2015, 158, 584-596. [CrossRef]

102. Chen, Y.; Vepa, R.; Shaheed, M.H. Enhanced and speedy energy extraction from a scaled-up pressure retarded osmosis process with a whale optimization based maximum power point tracking. Energy 2018, 153, 618-627. [CrossRef]

103. Maisonneuve, J.; Chintalacheruvu, S. Increasing osmotic power and energy with maximum power point tracking. Appl. Energy 2019, 238, 683-695. [CrossRef]

104. Manzoor, H.; Selam, M.A.; Abdur Rahman, F.B.; Adham, S.; Castier, M.; Abdel-Wahab, A. A tool for assessing the scalability of pressure-retarded osmosis (PRO) membranes. Renew. Energy 2019. [CrossRef]

105. Ettouney, H.; Al-Hajri, K. Modeling and performance analysis of forward and pressure-retarded osmosis. Desalin. Water Treat. 2019, 154,1-13. [CrossRef]

106. Chen, Y.; Alanezi, A.A.; Zhou, J.; Altaee, A.; Shaheed, M.H. Optimization of module pressure retarded osmosis membrane for maximum energy extraction. J. Water Process Eng. 2019, 32, 100935. [CrossRef]

107. Touati, K.; Tadeo, F. Study of the Reverse Salt Diffusion in pressure retarded osmosis: Influence on concentration polarization and effect of the operating conditions. Desalination 2016, 389, 171-186. [CrossRef]

108. Jung, D.H.; Lee, J.; Kim, D.Y.; Lee, Y.G.; Park, M.; Lee, S.; Yang, D.R.; Kim, J.H. Simulation of forward osmosis membrane process: Effect of membrane orientation and flow direction of feed and draw solutions. Desalination 2011, 277, 83-91. [CrossRef]

109. Bui, N.-N.; Arena, J.T.; McCutcheon, J.R. Proper accounting of mass transfer resistances in forward osmosis: Improving the accuracy of model predictions of structural parameter. J. Membr. Sci. 2015, 492, 289-302. [CrossRef]

110. Tang, C.Y.; Chong, T.H.; Fane, A.G. Colloidal interactions and fouling of NF and RO membranes: A review. Adv. Colloid Interface Sci. 2011, 164, 126-143. [CrossRef] [PubMed]

111. Tran, T.T.D.; Park, K.; Smith, A.D. Performance Analysis for Pressure Retarded Osmosis: Experimentation With High Pressure Difference and Varying Flow Rate, Considering Exposed Membrane Area. In Proceedings of the ASME 2016 International Mechanical Engineering Congress and Exposition IMECE, Phoenix, AZ, USA, 11-17 November 2016.

112. Seker, M.; Buyuksari, E.; Topcu, S.; Sesli, D.; Celebi, D.; Keskinler, B.; Aydiner, C. Effect of process parameters on flux for whey concentration with NH3/CO2 in forward osmosis. Food Bioprod. Process. 2017, 105, 64-76. [CrossRef]

113. Gulied, M.; Al Momani, F.; Khraisheh, M.; Bhosale, R.; AlNouss, A. Influence of draw solution type and properties on the performance of forward osmosis process: Energy consumption and sustainable water reuse. Chemosphere 2019, 233, 234-244. [CrossRef] [PubMed]

114. Hickenbottom, K.L.; Vanneste, J.; Elimelech, M.; Cath, T.Y. Assessing the current state of commercially available membranes and spacers for energy production with pressure retarded osmosis. Desalination 2016, 389, 108-118. [CrossRef]

115. Wang, C.; Li, Y.; Wang, Y. Treatment of greywater by forward osmosis technology: Role of the operating temperature. Environ. Technol. 2019, 40, 3434-3443. [CrossRef] [PubMed]

116. Touati, K.; Tadeo, F.; Hänel, C.; Schiestel, T. Effect of the operating temperature on hydrodynamics and membrane parameters in pressure retarded osmosis. Desalin. Water Treat. 2015, 57, 10477-10489. [CrossRef]

117. Shin, S.; Kim, A.S. Temperature Effect on Forward Osmosis. In Osmotically Driven Membrane Processes-Approach, Development and Current Status; IntechOpen: London, UK, 2018.

118. Touati, K.; Tadeo, F. Chapter Three-Effects of the Temperatures on PRO. In Pressure Retarded Osmosis; Touati, K., Tadeo, F., Chae, S.H., Kim, J.H., Alvarez-Silva, O., Eds.; Academic Press: Cambridge, MA, USA, 2017; pp. 97-128.

119. Anastasio, D.D.; Arena, J.T.; Cole, E.A.; McCutcheon, J.R. Impact of temperature on power density in closed-loop pressure retarded osmosis for grid storage. J. Membr. Sci. 2015, 479, 240-245. [CrossRef] 
120. Zhao, S.; Zou, L. Effects of working temperature on separation performance, membrane scaling and cleaning in forward osmosis desalination. Desalination 2011, 278, 157-164. [CrossRef]

121. Phuntsho, S.; Vigneswaran, S.; Kandasamy, J.; Hong, S.; Lee, S.; Shon, H.K. Influence of temperature and temperature difference in the performance of forward osmosis desalination process. J. Membr. Sci. 2012, 415-416, 734-744. [CrossRef]

122. Kim, Y.C.; Elimelech, M. Potential of osmotic power generation by pressure retarded osmosis using seawater as feed solution: Analysis and experiments. J. Membr. Sci. 2013, 429, 330-337. [CrossRef]

123. Heo, J.; Chu, K.H.; Her, N.; Im, J.; Park, Y.-G.; Cho, J.; Sarp, S.; Jang, A.; Jang, M.; Yoon, Y. Organic fouling and reverse solute selectivity in forward osmosis: Role of working temperature and inorganic draw solutions. Desalination 2016, 389, 162-170. [CrossRef]

124. Wang, Q.; Zhou, Z.; Li, J.; Tang, Q.; Hu, Y. Investigation of the reduced specific energy consumption of the RO-PRO hybrid system based on temperature-enhanced pressure retarded osmosis. J. Membr. Sci. 2019, 581, 439-452. [CrossRef]

(C) 2020 by the authors. Licensee MDPI, Basel, Switzerland. This article is an open access article distributed under the terms and conditions of the Creative Commons Attribution (CC BY) license (http://creativecommons.org/licenses/by/4.0/). 